\title{
Eliminating the Continuing Effects of the Violation: Compensatory Education as a Remedy for Unlawful School Segregation
}

\author{
Tracy Ellen Sivitz
}

In Milliken v. Bradley [Milliken II], ${ }^{1}$ the Supreme Court upheld as constitutional the inclusion of educational programs in school desegregation decrees. ${ }^{2}$ During the decade since Milliken II was decided, federal courts have ordered municipal and state governments to spend millions of dollars $^{3}$ for educational remedies in school districts which have intentionally segregated students on the basis of race. ${ }^{4}$ Known as "compensatory education," programs such as early childhood intervention, curriculum development, ${ }^{6}$ reduction in pupil-teacher ratios, ${ }^{7}$ counseling and career

1. 433 U.S. 267 (1977).

2. See infra text accompanying notes 21-45.

3. See, e.g., Jenkins v. Missouri, 672 F. Supp. 400, 409 (W.D. Mo. 1987):

\begin{tabular}{lr} 
1987-88 Desegregation Budget & \\
\hline Public Information & $\$ 30,000.00$ \\
Desegregation Monitoring Committee & $\$ 256,228.00$ \\
Effective Schools & $\$ 6,555,000.00$ \\
Reduction in Class Size & $\$ 8,450,135.00$ \\
Summer School & $\$ 1,295,764.00$ \\
Full Day Kindergarten & $\$ 1,826,964.00$ \\
Before- and After-School Tutoring & $\$ 233,759.00$ \\
Early Childhood Education & $\$ 3,102,178.00$ \\
Long Range Magnet Schools & $\$ 17,137,993.00$ \\
1986-87 Magnet Schools & $\$ 12,257,529.00$ \\
AAA Achievement & $\$ 6,340,614.00$ \\
Facilities Improvement (Interest) & $\$ 353,061.00$ \\
TOTAL & $\$ 57,839,225.00$
\end{tabular}

4. Terms used to denote intentional or unconstitutional school segregation, as opposed to de facto segregation which is lawful, include "de jure segregation" and "dual school system."

5. See, e.g., Jenkins v. Missouri, 639 F. Supp. 19, 32 (W.D. Mo. 1985), aff'd, 807 F.2d 657 (8th Cir. 1986), cert. denied, 108 S. Ct. 70 (1987); Liddell v. Missouri, 567 F. Supp. 1037, 1050 (E.D. Mo. 1983), affd, 731 F.2d 1294 (8th Cir.), cert. denied, 469 U.S. 816 (1984); Arthur v. Nyquist, 514 F. Supp. 1133, 1139 (W.D.N.Y. 1981), affd mem., 661 F.2d 907 (2d Cir.), cert. denied, 454 U.S. 1085 (1981).

6. See, e.g., Berry v. School Dist., 515 F. Supp. 344, 373-74 (W. D. Mich. 1981), affd, 698 F.2d 813 (6th Cir.), cert. denied, 464 U.S. 892 (1983); United States v. Board of School Comm'rs of Indianapolis, 506 F. Supp. 657, 672 (S.D. Ind. 1979), vacated in part on other grounds, 637 F.2d 1101 (7th Cir.), cert. denied, 449 U.S. 838 (1980); Evans v. Buchanan, 447 F. Supp. 982, 1016 (D. Del.), affd, 582 F.2d 750 (3d Cir. 1978) (en banc), cert. denied, 446 U.S. 923 (1980).

7. See, e.g., Jenkins v. Missouri, 639 F. Supp. at 28-30; Liddell v. Missouri, 567 F. Supp. at 1050. 
guidance, ${ }^{8}$ remedial reading, ${ }^{9}$ and staff development ${ }^{10}$ have become a regular part of school desegregation decrees.

Recent developments in the case law threaten the future of compensatory education relief and suggest that some courts have not understood Milliken IIs contribution to the Supreme Court jurisprudence defining the proper scope of school desegregation remedies. This Note argues that Milliken II extended prior doctrine by recognizing a broader range of legally redressable effects of segregation. First, Milliken II created the possibility for the complete elimination of segregation's systemic effects; the opinion sanctioned the remediation of any school practices or policies found to be administered in a discriminatory manner. ${ }^{11}$ Second, the Milliken II Court found it constitutionally permissible for federal courts to remedy individualized effects, such as student deficiencies in reading and communication skills, that segregation inflicts on the educational development of black pupils. The Court recognized that these individualized vestiges of segregation, which can persist despite a desegregating school system's progress in combatting racial discrimination, require affirmative remedial intervention if unconstitutional segregation and its effects are to be eliminated fully. ${ }^{12}$

Milliken II marked an important advance not only for school desegregation jurisprudence, but for equal protection doctrine generally. Antidiscrimination law too often has failed to pay adequate attention to the institutionalized nature of racial segregation, its ability to continue to visit debilitating physical, social, and economic consequences on generation after generation of victims, long after intentional discriminatory acts have ceased. ${ }^{13}$ As Eric Schnapper has pointed out, "vestiges of past discrimination do not exist gratuitously or only to a small degree-creating system-

8. See, e.g., United States v. Board of Educ. of Chicago, 588 F. Supp. 132, 167 (N.D. III.), vacated on other grounds, 744 F.2d 1300 (7th Cir. 1984), cert. denied, 471 U.S. 1116 (1985); United States v. Board of School Comm'rs of Indianapolis, 506 F. Supp. at 672-73; Reed v. Rhodes, 455 F. Supp. 569, 599 (N.D Ohio 1978), affd, 607 F.2d 714 (6th Cir. 1979), cert. denied, 445 U.S. 935 (1980).

9. See, e.g., United States v. Board of School Comm'rs of Indianapolis, 506 F. Supp. at 673; Reed v. Rhodes, 455 F. Supp. at 598-99; Evans v. Buchanan, 447 F. Supp. at 1015-16.

10. See, e.g., United States v. Yonkers Bd. of Educ., 635 F. Supp. 1538, 1551, app. C at 1572 (S.D.N.Y. 1986), affd, 837 F.2d 1181 (2d Cir. 1987), cert. denied 108 S. Ct. 2821 (1988); Berry v. School Dist., 515 F. Supp. at 376-79; Kelley v. Metropolitan County Bd. of Educ., 511 F. Supp. 1363, 1371 (M.D. Tenn. 1981), rev'd in part on other grounds, 687 F.2d 814 (6th Cir. 1982), cert. denied, 459 U.S. 1183 (1983).

11. See infra text accompanying notes 26-33.

12. See infra text accompanying notes $34-45$.

13. See Schnapper, Perpetuation of Past Discrimination, 96 HaRv. L. Rev. 828, 855 (1983); Laurence, One More River to Cross-Recognizing the Real Injury in Brown: A Prerequisite to Shaping New Remedies, in Shades of BRown 62 (D. Bell ed. 1980) ("White Americans deny responsibility for the position of blacks by denying that they have created a system of oppression that will continue to exist and operate to their benefit until they have destroyed it."); see also infra notes 22-23. 
atic, pervasive, and enduring vestiges is what effective discrimination was and is all about."14

Two emerging trends in the case law threaten to deny some black victims of segregation their constitutional right to compensatory education relief. The Fourth Gircuit recently limited the responsibility of school board or state actors to eliminate the effects of their own unconstitutional conduct on the educational development of black pupils. ${ }^{16}$ In addition, circuit courts are formulating guidelines for the achievement of unitary status that slight and even disregard the legal relevance of compensatory education relief. ${ }^{18}$

Section One of this Note examines Milliken Ir's contribution to school desegregation jurisprudence. Section Two analyzes federal decisions applying Milliken II, setting forth the various remedial avenues pursued, and criticizing the Fourth Circuit's recent Richmond desegregation case. It argues that it is fully within the equitable discretion of federal district courts to order educational relief for currently enrolled students suffering individualized educational deprivation caused by their school system's prior unconstitutional segregation, whether or not those students actually attended the racially segregated schools. Section Three maintains that a correct approach to terminating desegregation decrees must incorporate Milliken II's recognition that the elimination of all vestiges of segregation, and thus the achievement of unitary status, may require educational relief.

\section{Milliken II}

The Milliken II decision significantly advanced prior desegregation jurisprudence by holding that complete remediation of unconstitutional racial segregation and its effects may require eliminating not only widespread systemic or institutional effects of the violation, but also the individualized educational harms produced by segregation. ${ }^{17}$ The issue before the Court was whether the Gonstitution permitted a federal court to order the defendant State of Michigan to spend $\$ 8.5$ million for four compensatory education programs as part of a school desegregation de-

14. Schnapper, supra note 13 , at 839 .

15. See School Bd. of Richmond v. Baliles, 829 F.2d 1308 (4th Cir. 1987), affg Bradley v. Baliles, 639 F. Supp. 680 (E.D. Va. 1986); see also infra notes 75-95 and accompanying text.

16. The achievement of a "unitary" school system in which the violation of intentional segregation and all of its effects have been eliminated is the goal of every desegregation remedy. See, e.g., Green v. County School Bd., 391 U.S. 430, 437-38 \& n.4 (1968); see also infra Section III.

17. Just three years earlier, in Milliken v. Bradley, 418 U.S. 717 (1974) [Milliken I], the Supreme Court reversed the Sixth Circuit, which had upheld a district court order mandating an interdistrict pupil assignment remedy to "achieve the greatest degree of actual desegregation . . . ." Bradley v. Milliken, 345 F. Supp. 914, 918 (E.D. Mich. 1972), quoted in Milliken I, 418 U.S. at 734. The Supreme Court had found no interdistrict violation to sustain such a remedy, and remanded the case, directing the lower court to formulate an intradistrict remedy aimed at eliminating the segregation within the $71.5 \%$ black school district. See Milliken I, 418 U.S. at 752-53. 
cree. ${ }^{18}$ Some state defendants had argued that remedying unlawful segregation of students on the basis of race should be limited to correcting racially-skewed pupil assignment policies. ${ }^{19}$ While prior Supreme Court doctrine had already rejected this argument, the Milliken II Court thoroughly dispelled it. ${ }^{20}$

Invoking the classics of its desegregation jurisprudence, the Court derived a set of three principles to govern a lower court's exercise of equitable discretion in school desegregation suits. ${ }^{21}$ First, the nature of the desegregation remedy should be determined by the nature and scope of the constitutional violation. ${ }^{22}$ It therefore must be related to "the condition that offends the Constitution." ${ }^{23}$ Second, the decree should be remedial, designed as nearly as possible "to restore the victims of discriminatory conduct to the position they would have occupied in the absence of such conduct." 24 Third, in formulating a decree, the federal courts "must take

18. The four education components, proposed by both the plaintiffs and the defendant Detroit Board of Education, were: revised testing procedures, new guidance and counseling programs, inservice training for teachers and administrators, and a remedial reading and communications program. See Milliken II, 433 U.S at 272 \& n.5. The Detroit school board had also proposed, in addition to pupil reassignments, nine other compensatory programs that the State did not dispute. These included programs involving school-community relations, parental involvement, student rights and responsibilities, accountability, curriculum design, bilingual education, multi-ethnic curriculum, and co-curricular activities. See id. at 272 n. 5 .

19. See 433 U.S. at 273 n.8.

20. See infra notes $21-45$ and accompanying text.

21. The basic rule that federal courts should be guided by equitable principles in formulating desegregation decrees was established in Brown v. Board of Educ., 349 U.S. 294, 300 (1955) [Brown II].

22. Swann v. Charlotte-Mecklenburg Bd. of Educ., 402 U.S. 1, 16 (1971).

School desegregation case law follows the "corrective" approach to anti-discrimination law. See Gewirtz, Choice in the Transition: School Desegregation and the Corrective Ideal, 86 Colum. L. REv. 728 (1986). Corrective principles call for eliminating purposeful discriminatory conduct and its continuing effects in order to make whole the victims of a constitutional violation. For rejection of the anti-discrimination principle's focus on eliminating intentional discrimination and its effects, see Fiss, Groups and the Equal Protection Clause, 5 PHIL. \& PuB. Aff. 107, 147-70 (1976) (arguing for "group-disadvantaging principle" which would eliminate those laws or practices that particularly hurt disadvantaged groups); Fiss, The Supreme Court, 1978 Term-Foreword: The Forms of Justice, 93 HaRv. L. REv. 1, 47 (1979) (remedy should be aimed at social conditions, not individual incidents of wrongdoing); Freeman, Legitimizing Racial Discrimination through Antidiscrimination Law: A Critical Review of Supreme Court Doctrine, 62 MiNN. L. REv. 1049, 1053-54 (1978) (antidiscrimination principle exemplifies perpetrator's rather than victim's approach to racial discrimination by reducing discrimination from being social phenomenon to merely misguided conduct of particular actors).

23. Milliken I, 418 U.S. at 738 (quoting Swann, 402 U.S. at 16). Corrective approaches can be broadly or narrowly construed. See Gewirtz, supra note 22, at 731. School desegregation remedies are narrowly construed, directed not at broad continuing effects of slavery or one hundred years of Jim Crow laws, but at eliminating the violation and effects of identifiable acts of school segregation.

24. Milliken I, 418 U.S. at 746.

The Court devoted only a footnote to the issue of the practical limitations that courts of equity ordering compensatory education relief should consider. See 433 U.S. at 280-81 n.15. The Supreme Court had held in prior cases concerned with pupil assignment remedies that its broad goal of eliminating de jure segregation and all of its continuing effects might in some circumstances be sacrificed to other interests. See Gewirtz, Remedies and Resistance, 92 YALE L.J. 585, 600 (1983) (Supreme Court desegregation jurisprudence pursues interest-balancing approach in which costs may operate as independent constraint on full vindication of victims' rights).

In Milliken $I I$, the Court reiterated its long-held position that "consideration must be given to 
into account the interests of state and local authorities in managing their own affairs, consistent with the Constitution."25

The Court turned first to the systemic effects at issue in the case: the record revealed that two of the four educational practices in dispute-testing and counseling-had been administered by the Detroit public school system in a discriminatory manner ${ }^{28}$ The Supreme Court upheld reform of these programs as crucial to eliminating the continuing systemic harms of the dual school system. ${ }^{27}$

The Supreme Court had for some time recognized that achieving a discrimination-free public school system could involve more than addressing pupil assignment patterns. ${ }^{28}$ In its 1968 opinion in Green v. County School Board, the Court stated that the racial identification of schools extends "not just to the composition of student bodies . . . but to every facet of school operations-faculy [sic], staff, transportation, extracurricular activities, and facilities." ${ }^{29}$ And in Swann v. Charlotte-Mecklenburg Board of Education, the Supreme Court said that the "first remedial responsibility of school authorities is to eliminate invidious racial distinctions" in these areas. ${ }^{30}$ Yet, the Milliken II opinion moved beyond these cases in its appreciation of both the breadth of segregation's systemic effects and their unique manifestation in individual cases. According to the Milliken II Court, the "condition" to be remedied was Detroit's de jure segregated school system, and it deferred to the district court's specific factual findings as to which elements of the school system remained tainted by discrimination and thus stood in need of legal remediation. ${ }^{31}$

burdensome effects resulting from a decree that could 'either risk the health of the children or significantly impinge on the educational process." " 433 U.S. at 280 n.15 (quoting Swann, 402 U.S. at 30-31). According to the Court, remedial decrees should "desegregate an educational system in which the races have been kept apart, without, at the same time, losing sight of the central educational function of the schools." Id. (quoting Milliken I, 418 U.S. at 764 (White, J. dissenting))(emphasis in original).

However, the Court's concerns for interest-balancing centered on the costs of busing. In an exemplary footnote, the Court praised the district judge's "great pains" to devise a workable plan with a minimum of pupil transportation. See 433 U.S. at $288 \mathrm{n} .19$. None of the limiting principles it had derived in the pupil assignment area were applicable to the compensatory education components at issue. See id. at 288.

25. Milliken $I I, 433$ U.S. at 281 .

26. See id. at $274-75$.

27. See id. at $282-83$.

28. The Brown opinion itself discusses only segregated attendance patterns as the discriminatory mechanism harming black pupils. See Brown v. Board of Educ., 347 U.S. 483, 494 (1954) [Brown I]. The arguments of NAACP counsel shaped the opinion. See Carter, Reexamining Brown Twenty-Five Years Later: Looking Backward into the Future, 14 HARv. C.R.-C.L. L. REv. 615, 617 (1979) ("TT]he basic postulate of our strategy and theory in Brown was that the elimination of enforced, segregated education would necessarily result in equal education.").

29. 391 U.S. 430, 435 (1968); see also United States v. Montgomery County Bd. of Educ., 395 U.S. 225 (1969) (upholding specific numerical ratios for faculty and staff desegregation). For a discussion of some courts' misapplication of these indicia in the termination case law, see infra notes 105-08 and accompanying text.

30. 402 U.S. 1, 18 (1971).

31. See Milliken II, 433 U.S. at 282. According to the Court, "discriminatory student assignment policies can themselves manifest and breed other inequalities built into a dual system founded on 
The Milliken II decision also recognized that merely eliminating discrimination in current school practices will not always completely alleviate systemic harms. New programs might also be needed to end ongoing discrimination and to facilitate the desegregation process. Thus, the Supreme Court upheld an in-service training program for teachers because the district court had found it necessary both to instruct teachers and administrators to treat all students in a non-discriminatory manner ${ }^{32}$ and to prepare them to cope with the special problems presented by desegregation. ${ }^{33}$

Milliken IT s greatest contribution to desegregation jurisprudence was its recognition that individualized effects of the violation must also be remedied if the rights of black victims of segregation are to be vindicated. The Supreme Court described the individualized effects caused by Detroit's segregated school system:

Children who have been thus educationally and culturally set apart from the larger community will inevitably acquire habits of speech, conduct, and attitudes reflecting their cultural isolation. They are likely to acquire speech habits, for example, which vary from the environment in which they must ultimately function and compete, if they are to enter and be a part of that community. ...

Pupil assignment alone does not automatically remedy the impact of previous, unlawful educational isolation; the consequences linger and can be dealt with only by independent measures. ${ }^{34}$

Accordingly, the Court upheld the remedial and communications skills program ordered by the district court, as "aptly tailored to remedy the consequences of the constitutional violation." 35

Milliken II was not the first case in which the Supreme Court found that harms which exist independently of current school programs and practices are constitutionally redressable. In both Swann v. CharlotteMecklenburg Board of Education ${ }^{36}$ and Keyes v. School District No. $1,{ }^{37}$ the Court devoted considerable attention to examining how unlawful school construction and closing policies create segregated residential neighborhoods, which in turn contribute to continuing racial segregation in

racial discrimination. Federal courts need not, and cannot, close their eyes to inequalities, shown by the record, which flow from a longstanding segregated system." Id. at 283.

32.

Teachers, both white and black, often have unhealthy expectations of the ability and worth of students of the opposite race. Moreover, it is known that teachers' expectations vary with socio-economic variations among students. These expectations must, through training, be reoriented to ensure that academic achievement of black students in the desegregation process is not impeded.

402 F. Supp. 1096, 1139 (E.D. Mich. 1975).

33. See id. at 1139 .

34. 433 U.S. at 287-88.

35. Id. at 287.

36. 402 U.S. 1 (1971).

37. 413 U.S. 189 (1973). 
schools. ${ }^{38}$ The Court held in Swann that courts may order pupil assignment remedies which correct for the residential housing effects of the prior segregation. ${ }^{39}$

Although the Supreme Court did not reach the issue of remedying individualized educational harms until Milliken $I I{ }^{40}$ federal courts of appeals decisions for years had upheld orders of remedial education relief designed to overcome the educational deprivation suffered by black students. ${ }^{\mathbf{1 1}} \mathrm{Re}-$ medial rationales in those cases had included "compensat[ing] minority group children for unequal educational opportunities resulting from past or present racial and ethnic isolation . .." Although the Milliken II Court did not assess the constitutionality of these prior holdings, it stated that they supported the Court's broader principle that "[compensatory education] programs may . . . be appropriate remedies to treat the condition that offends the Constitution." 4 since the Supreme Court had defined this "condition" as "Detroit's de jure segregated school system," it it clearly envisioned that any school system whose pupils bore the effects of its prior intentional segregation remained a segregated system. ${ }^{45}$

In 1977, the future of compensatory education relief probably was unclear. The Milliken II facts seemed unique: the educational components required minimal government expense; the plaintiffs and local school board were aligned against the state; and though Milliken $I$ had foreclosed an interdistrict pupil assignment remedy, Detroit school children desperately required some relief. ${ }^{46}$ Over the next decade, lower federal courts would give content to Milliken ITs equitable principles in the complex desegregation suits that confronted them.

38. According to these cases, before accepting a school board's claim that private demographic choices and not intentional school board actions created segregated schools, courts should scrutinize the school board's own liability for contributing to segregated housing patterns. See Swann, 402 U.S. at 20-21; Keyes, 413 U.S. at 211-12.

39. See 402 U.S. at 20-21.

40. See Milliken II, 433 U.S. at 283-86.

41. See, e.g., Morgan v. Kerrigan, 530 F.2d 401 (1st Cir.), cert. denied, 426 U.S. 935 (1976);

Hart v. Community School Bd., 512 F.2d 37 (2d Cir. 1975); Plaquemines Parish School Bd. v. United States, 415 F.2d 817 (5th Cir. 1969); Stell v. Board of Pub. Educ. of Savannah, 387 F.2d 486 (5th Cir. 1967); United States v. Jefferson County Bd. of Educ., 380 F.2d 385 (5th Cir.), cert. denied, 389 U.S. 840 (1967).

42. 433 U.S. at 285 (quoting United States v. Texas, 447 F.2d 441, 448 (5th Cir. 1971), cert. denied, 404 U.S. 1016 (1972)).

43. 433 U.S. at 286 n.17 (emphasis added).

44. See id. at 282; supra text accompanying note 31 .

45. The Court also stressed that eliminating individualized harms would require a considerable amount of time and effort, for compensatory programs

were not, and as a practical matter could not be, intended to wipe the slate clean by one bold stroke... Rather, by the nature of the antecedent violation, which on this record caused significant deficiencies in communications skills-reading and speaking-the victims of Detroit's de jure segregated system will continue to experience the effects of segregation until such future time as the remedial programs can help dissipate the continuing effects of past misconduct. ...

433 U.S. at 290.

46. See Gewirtz, supra note 24 , at 656 n.197. 


\section{Milliken II and the Lower Federal Courts}

Many lower courts have invoked Milliken II's remedial principles to eradicate systemic and individualized vestiges of unconstitutional segregation. ${ }^{47}$ However, some recent opinions have failed to grant full relief to individualized harms. ${ }^{48}$ Part $\mathrm{A}$ sets forth those avenues of relief which have emerged in the case law to remedy systemic vestiges of school segregation. ${ }^{49}$ Part B examines the federal courts' approaches to remedying individualized educational harms. It criticizes the recent Richmond desegregation opinions $s^{50}$ and argues that, contrary to those holdings, compensatory education relief should be provided in a school district when the educational deprivation of its pupils can be linked to prior unlawful segregation.

47. In order for its desegregation decree to be constitutionally permissible, a court must find that the harms or conditions that its decree seeks to redress were actually caused by unlawful segregation. See, e.g., Morgan v. McKeigue, 726 F.2d 33 (1st Cir. 1984) (portion of district court order mandating school committee funding for city-wide parents council vacated where district court made no findings linking expenditure to achievement of valid desegregation goals).

In order to disentangle the causal nexus leading to both systemic inequalities and individualized educational deprivation, many courts have used a presumption similar to that invoked at the liability stage to determine responsibility for the existence of racially identifiable schools. See, e.g., Vaughns v. Board of Educ. of Prince George's County, 758 F.2d 983, 991 (4th Cir. 1985) (holding district court erred in placing on plaintiffs burden of proving that present racial disparities in placement in special education and gifted programs were causally related to pre-1973 segregation); Oliver v. Kalamazoo Bd. of Educ., 640 F.2d 782, 811 (6th Cir. 1980) (agreeing that "at the inception of a desegregation effort ... the district court could, in ordering ancillary programs, presume that the disparity in achievement was related to the segregated schools"). But see Tasby v. Estes, 643 F.2d 1103, 1108 (5th Cir. 1981) (arguing in context of school discipline that "[t]oo many legitimate, non-racial factors are involved to permit an inference of discriminatory purpose from a showing of disproportionate impact, even when it occurs in the context of on-going desegregation efforts.").

This Keyes presumption shifts the burden of proof to constitutional violators to prove that conditions of segregation are not the result of intentionally discriminatory actions on their part. See Keyes v. School Dist. No. 1, 413 U.S. 189, 208 (1973); Dayton Bd. of Educ. v. Brinkman, 443 U.S. 526, 537-38, 541 (1979) [Dayton II]. But see Goodman, Some Reflections on the Supreme Court and School Desegregation, in Race and Schooling IN THE Crry 45-83 (A. Yarmolinsky, L. Liebman \& C. Schelling eds. 1981) (challenging causal hypothesis underlying presumption that prior segregation has shaped present racial composition of violator school districts).

The most important underlying rationales for the imposition of burdens of proof are probability, fairness, and policy. See Keyes, 413 U.S. at 209 (quoting J. Wigmore, EvidenCE § 2486, at 275 (3d ed. 1940)) (burden of proof issue "merely a question of policy and fairness based on experience in the different situations"); Note, Allocating the Burden of Proof After A Finding of Unitariness in School Desegregation Litigation, 100 HARv. L. REv. 653, 657-60 (1987).

Courts have borrowed the burden-shifting techniques traditionally applied to pupil assignment effects for the purpose of assessing responsibility for systemic and individualized educational harms. In doing so, these courts have affirmed Milliken II's holding that such harms also be seen as a "condition that offends the Constitution." See supra notes $21-45$ and accompanying text.

48. See discussion infra notes 75-95 and accompanying text.

49. Some compensatory education programs, such as pre-kindergarten or summer school, can achieve the elimination of both systemic and individualized harms. See, e.g., Jenkins v. Missouri, 639 F. Supp. 19 (W.D. Mo. 1985), affd, 807 F.2d 657 (8th Cir. 1986), cert. denied, 108 S. Ct. 70 (1987) (ordering many compensatory education programs both to facilitate voluntary inter-district transfer scheme and to eliminate educational deprivation suffered by individual students in the Kansas Gity, Missouri, school district as result of prior unlawful segregation).

50. See Bradley v. Baliles, 639 F. Supp. 680 (E.D. Va. 1986), affd sub nom. School Bd. of Richmond v. Baliles, 829 F.2d 1308 (4th Cir. 1987). 


\section{A. Eliminating Systemic Educational Effects}

In applying Milliken $I I$ to remedy the systemic vestiges of school segregation, three remedial goals have emerged in the case law: eliminating continuing discriminatory educational practices; ${ }^{61}$ facilitating pupil reassignment; ${ }^{62}$ and maintaining or inducing integrated attendance patterns. ${ }^{\text {s3 }}$

Little Rock School District v. Pulaski County Special School District No. $1^{54}$ illustrates the use of compensatory programs to eliminate the continuing vestiges of a segregated school system that persist as discriminatory educational practices. The district court approved new procedural safeguards proposed by the North Little Rock School District for determining the assignment of students to special education and gifted programs, after finding that the District had administered such programs in a discriminatory fashion. ${ }^{\text {b5 }}$ Plaintiffs had alerted the court to the fact that twenty percent of the black student body had been classified as mentally retarded or learning disabled; the court found that "[n]o valid testing procedure could end up placing one out of every four or five children in special education." ${ }^{218}$ In addition, only $9.4 \%$ of the gifted program students were black; according to the court, this was "an underrepresentation of blacks in the gifted program of 6.8 standard deviations, which would occur only seven times in a billion by chance."

In Evans v. Buchanan, ${ }^{88}$ which exemplifies the goal of facilitating pupil reassignment, the Third Circuit upheld, among other remedial components, programs which the district court had ordered in the areas of human relations, in-service training, and special counseling "to help students, parents, and faculty deal with the various pressures which arise as

51. See, e.g., Little Rock School Dist. v. Pulaski County, 584 F. Supp. 328, 349 (E.D. Ark. 1984), rev'd in part on other grounds, 778 F.2d 404 (8th Cir. 1985), cert. denied, 476 U.S. 1186 (1986); Reed v. Rhodes, 455 F. Supp. 569, 599 (N.D. Ohio 1978), affd, 607 F.2d 714 (6th Cir. 1979), cert. denied, 445 U.S. 935 (1980).

52. See, e.g., Evans v. Buchanan, 447 F. Supp. 982, 1015 (D. Del. 1978), affd, 582 F.2d 750 (3d Cir. 1978), cert. denied, 446 U.S. 923 (1980).

53. See, e.g., Jenkins v. Missouri, 639 F. Supp. 19, 26-35 (W.D. Mo. 1985), affd, 807 F.2d 657 (8th Cir. 1986), cert. denied, 108 S. Ct. 70 (1987); Arthur v. Nyquist, 712 F.2d 809, 811 (2d Cir. 1983), cert. denied, 466 U.S. 936 (1984).

54. 659 F. Supp. 363 (E.D. Ark. 1987) (ordering remedy), vacated in part on other grounds, 839 F.2d 1296 (8th Cir. 1988); 584 F. Supp. 328 (E.D. Ark. 1984) (finding liability), rev'd in part on other grounds, 778 F.2d 404 (8th Cir. 1985), cert. denied, 476 U.S. 1186 (1986).

55. See 659 F. Supp. at 367-68; 584 F. Supp. at 349.

In the Cleveland desegregation litigation, Reed v. Rhodes, 455 F. Supp. 569 (N.D. Ohio 1978), affd, 607 F.2d 714 (6th Cir. 1979), cert. denied, 445 U.S. 935 (1980), the district court found that racially imbalanced classes were partly the result of stereotyped counselling practices and course offerings. Among other things, the court ordered the defendant school board to "institute an effective nondiscriminatory counselling and career guidance program . . . to ensure that students [were] counselled on a racially nondiscriminatory basis as to opportunities in employment or higher education and as to vocational and special educational programs." Id. at 599.

56. Little Rock, 584 F. Supp. at 349.

57. Id.

58. 582 F.2d 750 (3d Cir. 1978) (en banc), affg 447 F. Supp. 982 (D. Del. 1978), cert. denied, 446 U.S. 923 (1980). 
a result of desegregation." ${ }^{\text {"59 }}$ Inducing integrated attendance or maintaining white enrollment has also become a widely-invoked rationale for ordering compensatory education relief. ${ }^{60}$ For example, in Arthur v. $\mathrm{Ny}$ quist, ${ }^{61}$ early childhood centers, special academies, and a general upgrading of the school system were ordered to maintain or attract the white enrollment needed to eliminate attendance pattern disparities caused by prior discrimination. ${ }^{62}$ The Second Circuit applauded the success of the district court in achieving desegregative goals with a minimum of mandatory busing "by establishing innovative programs . . . ."63

\section{B. Eliminating Individualized Educational Effects}

Federal cases ordering the eradication of individualized vestiges of segregation seek two remedial goals: remedying the individualized educational deprivation of currently enrolled pupils caused by the prior discriminatory acts of a school district or state actor, ${ }^{64}$ and removing individualized harms caused by the continuing racial isolation of students who will remain in racially identifiable schools under a desegregation plan. ${ }^{85}$

59. Id. at 769 (emphasis in original).

60. See, e.g., United States v. Yonkers Bd. of Educ., 635 F. Supp. 1538, 1541-42 (S.D.N.Y. 1986) (ordering magnet schools offering early childhood and other specialized educational programs as means to promote integration), aff d, 837 F.2d 1181 (2d Cir. 1987), cert. denied, 109 S. C.. 2821 (1988); Liddell v. Missouri, 731 F.2d 1294, 1309-12, 1313 (8th Cir. 1984) (upholding implementation of magnet schools and system-wide quality education improvements to encourage white enrollment), affg 567 F. Supp. 1037 (E. D. Mo. 1983), cert. denied, 469 U.S. 816 (1984).

Although the issue of resegregation was not addressed specifically in Milliken II, the opinion's remedial jurisprudence easily supports an integration-inducing rationale for compensatory education. One of the systemic harms of segregation is the continued existence of segregated attendance patterns and racially identifiable schools. Thus, educational programs designed to support or promote integration are clearly related to the goal of eliminating these discriminatory vestiges.

61. 514 F. Supp. 1133 (W.D.N.Y. 1981), aff d mem., 661 F.2d 907 (2d Cir.), cert. denied, 454 U.S. 1085 (1981).

62. See Arthur v. Nyquist, 712 F.2d 809, 811 (2d Cir. 1983), cert. denied, 466 U.S. 936 (1984).

Some scholars have cautioned that to the extent that compensatory programs are viewed primarily as a tool to induce integration, remedial programs designed to cure black educational deprivation may be sacrificed to general systemic improvements intended to attract white pupils. See Crain \& Mahard, How Desegregation Orders May Improve Minority Academic Achievement, 16 HARv. C.R.-C.L. L. REv. 693, 707 (1982) ("Concentration on methods designed to prevent white flight increases the likelihood that district funds will be diverted into services appealing to middle-class white parents at the expense of sacrificing compensatory and human relations programs meeting minority needs."). For a similar criticism levelled against the St. Louis desegregation plan, see D. MONTI, A SEMBLANCE OF JuSTICE: ST. LOUIS SCHOOL DESEGREGATION AND ORDER IN URBAN AMERICA (1985) (same school board which resisted liability for segregation for years was able to utilize school desegregation mandate to increase their legitimacy as proper policy-making authority for public education and to achieve funds to upgrade system with secondary priority given to black grievances); Snider, Increased Push for Desegregation Urged, EDuc. WEEK, Feb. 11, 1987, at 15, col. 3 (St. Louis school officiais criticized for lack of progress in implementing special academic programs in predominantly black city schools).

63. 712 F.2d at 811.

64. See, e.g., Jenkins v. Missouri, 639 F. Supp. 19, 24-26 (W.D. Mo. 1985), aff d, 807 F. 2d 657 (8th Cir. 1986), cert. denied, 108 S. Ct. 70 (1987); Berry v. School Dist., 515 F. Supp. 344, 369 (W.D. Mich. 1981), aff'd, 698 F. 2d 813 (6th Gir. 1983), cert. denied, 464 U.S. 892 (1983).

65. See, e.g., Liddell v. Missouri, 731 F.2d 1294, 1314 (8th Cir. 1984), affg 567 F. Supp. 1037 
In Berry v. School District, ${ }^{68}$ the district court ordered a social skills and achievement program as part of its desegregation plan with the goal of raising student achievement scores within the district to reach the average attained by students statewide. The Berry court had found that defendants "caused," "condoned," and "perpetuated" the "measurably reduced" achievement of black pupils. ${ }^{67}$ According to the court, the achievement program was "crucial to any complete and effective remediation" of that harm. ${ }^{88}$

Similarly, in Jenkins $v$. Missouri $i^{69}$ the district court ordered special remedial education programs after finding that segregation had caused a systemwide reduction in student achievement in the schools of the Kansas City Metropolitan School District. ${ }^{70}$ The court ordered, among other components, reduced class size, summer school programs, full-day kindergarten, and early childhood development programs in order to increase student achievement levels. ${ }^{71}$

Courts have also ordered remedial relief for students remaining in allblack schools under a desegregation plan. ${ }^{72}$ In Liddell v. Missouri, ${ }^{73}$ addi-

(E.D. Mo. 1983), cert. denied, 469 U.S. 816 (1984); United States v. Board of Educ. of Chicago, 588 F. Supp. 132, 159 (N.D. IIl.), vacated on other grounds, 744 F.2d 1300 (7th Cir. 1984), cert. denied, 471 U.S. 1116 (1985).

66. 515 F. Supp. 344 (W.D. Mich. 1981), aff d, 698 F. 2 d 813 (6th Cir. 1983), cert. denied, 464 U.S. 892 (1983).

67. See id. at 369. Other evidence of individualized harm might include drop-out and retention rates, and comparative statistics on black and white or district and non-district students that indicate the percentage of students reading at below-grade level, those graduating from high school in four years, and those continuing their education. See Bradley v. Baliles, 639 F. Supp. 680, 694-96 (E.D. Va. 1986), affd sub nom. School Bd. of Richmond v. Baliles, 829 F.2d 1308 (4th Cir. 1987).

68. 515 F. Supp. at 369.

69. 639 F. Supp. 19 (W.D. Mo. 1985), aff d, 807 F.2d 657 (8th cir. 1986), cert. denied, 108 S. Ct. 70 (1987).

70. See id. at 24; see also infra notes 80-82 and accompanying text. Test results from the Iowa Test of Basic Skills in grades 1 through 6 showed that only a few elementary schools of the fifty in the system were performing at or above the national norm in reading and mathematics. $639 \mathrm{~F}$. Supp. at 24.

71. See 639 F. Supp. at 28-33.

72. One major proponent of the use of compensatory education in all-black schools to replace mandatory busing is Derrick Bell. See Bell, The Burdens of Brown on Blacks: History-Based Observations on a Landmark Decision, 7 N.C. CENT. L. J. 25,37 (1975) [hereinafter Bell, Burdens of Brown! ("Effective schools are far more essential to the 'equal educational opportunity' promise in Brown than the achievement of racial balance in the student population ...."); see also D. BEL, AND We ARE Not SAved, 120-21 (1987); Bell, A Model Alternative Desegregation Plan, in SHADES OF BROWN, supra note 13, at 125.

Bell claims that denial of equal educational opportunity, not segregation, was the primary violation in Brown. See Bell, Burdens of Brown, supra, at 36. But see Jones, Correspondence, 86 YALE L.J. 378,379 (1976) ("[S]egregation is itself the deepest educational harm because it is the result of institutional racism and a condition of state-imposed racial caste."); Leubsdorf, Completing the Desegregation Remedy, 57 B.U.L. REv. 39, 48 (1977) ("[T]he main remedy is desegregation itself. Ancillary [compensatory] remedies have the smaller role of ending the lingering effects of the past violation and giving desegregation a fair chance to operate."); Bradley v. Baliles, 639 F. Supp. 680, 688 (E.D. Va. 1986) (redressing educational harms is ancillary to "primary goal of eliminating segregation itself"), affd sub nom. School Bd. of Richmond v. Baliles, 829 F.2d 1308 (4th Cir. 1987). The debate over the primacy of various aspects of the constitutional violation ignores the power of corrective principles to reach segregated attendance patterns and racial identifiability, as well as educational harms. See Gewirtz, supra note 22, at 774. For an approach to the violation emphasizing school governance, see 
tional class size reduction, and after-school remediation were ordered for such schools on the theory that "[w]hen no other feasible desegregation techniques exist, then specific remedial programs for students in the remaining one-race schools may be included as a means of ensuring equal educational opportunity." "74

Recently, however, the Fourth Circuit has placed a new constitutional limitation on the provision of educational remedies to correct individualized harms linked to prior unlawful segregation. In Bradley $v$. Baliles, ${ }^{76}$

Shane, School Desegregation Remedies and the Fair Governance of Schools, 132 U. PA. L. REv. 1041, 1043 (1984).

Bell also argues that court-ordered desegregation may inflict equal or more harm on black pupils than racially isolated compensatory programs, but he inadequately supports his empirical claim. See Bell, Burdens of Brown, supra, at 31 \& $\mathrm{nn}$. 27-28. The available social science evidence and experience indicate that an integrated education best prepares black children for participation in a pluralistic society, and that educational resources are most likely to flow to schools where white students are enrolled. See Gewirtz, supra note 22, at 776; W. Hawley \& S.J. Rosenholtz, ACHIEving Quality Integrated Education (1986); see also Crain, Hawes, Miller \& Peicher', A LongituDinal Study of a METropolitan Voluntary DeSEGREgation Plan (National Institute of Education Report No. 6-81-0062,1984) (black males attending desegregated schools more likely to graduate from high school, complete more years of college, perceive less discrimination in college and other areas of adult life, experience less difficulty with police, closer social contact with whites as adults, and more likely to live in desegregated housing); R.L. CRain \& J. Strauss, School. DesegRegation and Black Occupational AtTainments, Results from a LONG-TERM ExperiMENT 1 (1985) (desegregated students working in occupations less commonly held by blacks, more likely to be working in white-collar and professional jobs in private sector); DAwKINS \& BRADDOcK, School Desegregation and the Use of Soctal Networks to Locate Desegregated EMPLOYMENT (1985) (desegregation in adulthood helps blacks to use biracial social networks to obtain better employment).

This Note does not dispute Bell's claim that in certain circumstances, retaining black children in a segregated setting may outweigh the benefits of pupil assignment. In the Dallas desegregation litigation, compensatory education programs were ordered in lieu of achievable integration. See, e.g., Tasby v. Wright, 585 F. Supp. 453, 458 (N.D. Tex. 1984) (permitting resegregation of 2300 black children for purposes of remedial education in all-black schools), affd sub nom. Tasby v. Black Coalition to Maximize Educ., 771 F.2d 849 (5th Cir. 1985); Tasby v. Wright, 520 F. Supp. 683 (N.D. Tex. 1981) (additional K-3 busing rejected in part because of compensatory education programs already instituted in all-black schools), rev'd in part on other grounds, 713 F.2d 90 (5th Cir. 1983). However, before invoking compensatory programs as an adequate substitute for pupil reassignment, the court should have made an explicit factual finding that this resegregation-pluscompensatory education plan provided meaningful and immediate relief when compared to other more effective feasible alternatives. See, e.g., Green v. County School Bd., 391 U.S. 430, 439 (1968). For example, the court should have explained why it was that compensatory education programs could not be established in the partially integrated schools to which the students were being bused. In Dallas, where partial integration was all that was possible within the majority black school district, perhaps the court could have made such a finding.

73. 731 F.2d 1294 (8th Cir. 1984), affg 567 F. Supp. 1037 (E.D. Mo. 1983), cert. denied, 469 U.S. 816 (1984).

74. Id. at 1314; see also Little Rock School Dist. v. Pulaski County Special School Dist. No. 1, 778 F.2d 404, 408 (8th Cir. 1985) (compensatory and remedial programs should be put into effect in non-integrated schools), cert. denied, 476 U.S. 1186 (1986). The Eighth Gircuit held correctly that as a matter of law racially identifiable schools may receive additional compensation to assure equality of educational opportunity within the school district. See Liddell, 731 F.2d at 1314. But see Bradley v. Baliles, 639 F. Supp. 680, 694-95 (E.D. Va. 1986) (rejecting factual basis for assumption that racially isolated students in Richmond require more educational assistance, but using flawed methodology).

75. The Richmond school desegregation case, Bradley v. Baliles, 639 F. Supp. 680 (E.D. Va. 1986), affd sub nom. School Bd. of Richmond v. Baliles, 829 F.2d 1308 (4th Cir. 1987), has a tortured history extending for more than twenty years. In 1966, after finding defendant Richmond Public Schools liable for unlawful segregation, the district court approved a "freedom of choice" stu- 
the district court declared and the Fourth Circuit affirmed that it was "not within the [c]ourt's power" to remedy educational harms suffered by pupils who did not themselves attend de jure segregated schools. ${ }^{78}$ This self-imposed limitation on the district courts' remedial power conflicts with the practice of other federal courts which consider the effects of past segregation to include the educational deficiencies of current students caused by segregation-linked poverty. ${ }^{77}$ Neither Milliken IIS affirmative remedial principles nor its guidelines for limiting the exercise of equitable discretion in school desegregation cases preclude the courts from remedying such harms.

The Bradley court admitted that prior segregation had inflicted educational and socioeconomic injury on the black parents of current school children, and that these injuries had contributed to the children's poor academic performance: "[O]ne of the reasons for the high poverty rate in Richmond is the inferior education that was provided to blacks under the former dual system" and "one of the primary causes of the previous low achievement levels of RPS students was the high incidence of poverty in the system."78 The plaintiffs' expert witness at trial had presented a comprehensive analysis of data gathered from current students and parents which indicated a direct and statistically significant relationship between the low achievement scores of current school children and the degree to which their parents had been subjected to segregation. ${ }^{79}$ Nonetheless, the

dent assignment plan, which was subsequently amended in 1971 to require extensive mandatory reassignment. In 1972, the district court also found several surrounding school districts and the State Board of Education, which the plaintiffs had joined as additional defendants, liable for the unconstitutional segregation within Richmond. After holding that its 1971 desegregation plan would be ineffective in producing stable desegregation, the court ordered the consolidation of the majority-black Richmond school district with the surrounding majority-white districts. On appeal, the Fourth Circuit reversed, holding that an interdistrict remedy was not justified as there was insufficient evidence of an interdistrict violation. In 1984, the plaintiffs, with the Richmond Public School Board realigned as a plaintiff, brought a claim alleging that the State had failed in its constitutional obligation to eradicate the vestiges of segregation in the Richmond schools. See id. at 681-82.

76. Id. at $690-91 ; 829 \mathrm{~F} .2 \mathrm{~d}$ at $1313-14$.

This Note focuses on the legal arguments presented in the Bradley case on the issue of relief for individualized educational harms. Analysis of other problematic aspects of the lower court decision, such as its erroneous factual findings, are beyond the scope of this Note.

77. See, e.g., Little Rock School Dist. v. Pulaski County Special School Dist. No. 1, 659 F. Supp. 363, 368 (E.D. Ark. 1987) (approving special testing, teacher aides, supplemental reading instruction for "educationally disadvantaged" children "who continue to suffer the trickle down effects of past segregation ...."), vacated in part on other grounds, 839 F.2d 1296 (8th Cir. 1986); Jenkins v. Missouri, 807 F.2d 657 (8th Cir. 1986), affg 593 F. Supp. 1485 (W.D. Mo. 1984) (finding liability) (discussed infra notes 80-82 and accompanying text), 639 F. Supp. 19 (W. D. Mo. 1985) (ordering remedy), cert. denied 108 S. Ct. 70 (1987); Kelley v. Metropolitan School Bd. of Educ., 687 F.2d 814 (6th Cir. 1982), affg 511 F. Supp. 1363, 1368-69 (M.D. Tenn. 1981) (awarding educational remediation programs for "those schools or classes where the achievement levels are below the average for the system and/or where the majority of a school's population is made up largely of socioeconomically deprived children who suffer the continuing effects of prior discrimination"), cert. denied, 459 U.S. 1183 (1983).

78. Bradley v. Baliles, 639 F. Supp. 680, 690 (E.D. Va. 1986), affd sub nom. School Bd. of Richmond v. Baliles, 829 F.2d 1308 (4th Cir. 1987).

79. See Brief for Appellants at 34, School Bd. of Richmond v. Baliles, 829 F.2d 1308 (4th Cir. 1987)(No. 86-3106). 
court concluded that it was constitutionally barred from recognizing these effects as remediable.

In contrast, the district court's opinion in Jenkins $v$. Missouri, ${ }^{\mathbf{8 0}}$ upheld by the Eighth Circuit, quite easily recognized educational harms produced by segregation-related poverty as a basis for legal relief. The Jenkins court found that thirty years after state-mandated segregation had ceased in Missouri, black Kansas City schoolchildren's low achievement scores reflected the lingering effects of the old dual system. ${ }^{81}$ Review of the trial transcript citations noted by the district court in its factual findings reveals that the court repeatedly referred to testimony indicating that the dual school system had generated the black poverty in Kansas City:

[T] he dual system, in addition to causing low achievement which continues among blacks, generated a large, isolated poverty ghetto which reduced economic opportunities for familes[sic] and children, and in doing that, in turn created more low achievement, such that it wound up being a cycle, low achieving students with little chance to succeed economically who then raise children in a difficult environment and difficult schools in which their children fail. ${ }^{\mathbf{8 2}}$

Yet, according to the district court in Bradley, because pupils currently enrolled in the Richmond public schools had never attended de jure segregated schools, the only remediable educational harms were those existing within the school system itself..$^{33}$ Any individualized effects that the prior school segregation may have had on current Richmond Public School students were deemed "indirect," and therefore irremediable.

The court's characterization of the individualized harms as "indirect" and those remaining in the school system itself as "direct" reveals a bias in its remedial theory which is unsupported by Milliken II. ${ }^{84}$ According to

80. 593 F. Supp. 1485 (W.D. Mo. 1984), affd, 807 F.2d 657 (8th Cir. 1986), cert. denied, 108 S. Ct. 70 (1987).

81. See id. at 1492. The court stated its findings of fact regarding the Kansas City, Missouri School District:

Several witnesses confirmed the conclusion reached by the Supreme Court in Brown $I$ that forced segregation ruins attitudes and is inherently unequal: '[Segregation] may affect their hearts and minds in a way unlikely ever to be undone.' The general attitude of inferiority among blacks produces low achievement which ultimately limits employment opportunities and causes poverty. While it may be true that poverty results in low achievement regardless of race, it is undeniable that most poverty-level families are black. The District stipulated that as of 1977 they had not eliminated all the vestiges of the prior dual system. The Court finds the inferior education indigenous of [sic] the state-compelled dual school system has lingering effects in the Kansas City, Missouri School District.

Id. (citations to record omitted).

82. Record at 16,457-58, Jenkins, 593 F. Supp. 1485 (W.D. Mo. 1984) (No. 77-420-CV-W), affd, 807 F.2d 657 (8th Cir. 1986), cert. denied, 108 S. Ct. 70 (1987).

83. According to the district court, examples of such harms would be "racial bias in the tests administered by RPS, discrimination in the manner in which students are selected for various educational programs and inadequacy of current RPS teachers due to their attendance in inferior, segregated schools in RPS." 639 F. Supp. at 690.

84. For an analysis of the Milliken II opinion, see supra Section I. 
the Bradley court, the "primary defect" in segregated school systems is the "separate and inferior" treatment of blacks inherent in such systems: "The elimination of the vestiges of segregation, in areas such as student achievement, is ancillary to and separate from the primary goal of eliminating the segregation itself." ${ }^{85}$ Further, the Court asserted that "[t]he Constitution does not guarantee those students who have never personally been subjected to de jure school segregation the right to be free of all of the effects of prior segregation; rather, it only requires that such students be provided a non-discriminatory education."

This legal conclusion simply ignores Milliken II, which authorizes compensatory education programs necessary to remedy the effects of discrimination on both "the victims of segregation and the school system itself." Even the Bradley court recognized that federal courts have never required school desegregation plaintiffs to have attended a de jure segregated school before granting relief for systemic harms such as segregated attendance patterns or racially identifiable schools. Such a requirement would violate long-established Supreme Court desegregation jurisprudence which recognizes a continuing obligation on the part of school boards to eliminate all the effects of the violation, even as late as twenty-five years after statemandated or intentional segregation has ceased ${ }^{88}$ The Bradley court's constitutional "contribution," upheld by the Fourth Circuit, is to demand that plaintiffs have attended the school system if they seek relief for individualized harms. ${ }^{89}$

In limiting the scope of individualized relief, the Bradley court misread dicta in Swann v. Charlotte-Mecklenburg Board of Education which states that "[o]ne vehicle can carry only a limited amount of baggage."

\footnotetext{
85. 639 F. Supp. at 688 (emphasis in original).

86. Id. at 691 .

87. See Liddell v. Missouri, 731 F.2d 1294, 1315 (8th Cir. 1984), affg 567 F. Supp. 1037 (E.D. Mo. 1983), cert. denied, 469 U.S. 816 (1984).

88. See Dayton II, 443 U.S. 526, 537-38 (1979); Columbus Bd. of Educ. v. Penick, 443 U.S. 449 , 458-461 (1979); see also Keyes v. School Dist. No. 1, 413 U.S. 189, 200 (1973) (recognizing duty to remedy continuing effects); Swann v. Charlotte-Mecklenburg Bd. of Educ., 402 U.S. 1, 15 (1971) (same); Jenkins v. Missouri, 593 F. Supp. 1485, 1504 (W.D. Mo. 1984) (Brown II, Green, Swann, Keyes and Dayton $I I$, among other cases, stand for proposition that having created a dual system, state and school district have continuing obligation to disestablish it), affd, 807 F.2d 657 (8th Cir. 1986),
} cert. denied, 108 S. Ct. 70 (1987).

89. But see Jenkins, 593 F. Supp at 1490, 1492 (finding low achievement levels of students attending Kansas City schools in 1984 remediable as lingering effects of state-compelled dual school system that existed in 1954); Jenkins, 639 F. Supp. 19 (W.D. Mo. 1985) (ordering remedy).

None of the federal courts that have ordered Milliken II relief for individualized educational deprivation have limited their remedies to students who had been enrolled in the de jure segregated school system. In fact, many remedial programs are targeted to pre-school and elementary school children, who are too young to have attended the segregated system. See, e.g., Tasby v. Wright, 585 F. Supp. 453, 455-56 (N.D. Tex. 1984), aff'd sub nom. Tasby v. Black Coalition to Maximize Educ., 771 F.2d 849 (5th Cir. 1985); Jenkins v. Missouri, 639 F. Supp. 19, 28-34 (W.D. Mo. 1985), affd, 807 F.2d 657 (8th Cir. 1986), cert. denied, 108 S. Ct. 70 (1987); Berry v. School Dist., 515 F. Supp. 344, 372 (W.D. Mich. 1981), affd, 698 F.2d 813 (6th Cir. 1983), cert. denied, 464 U.S. 892 (1983).

90. Bradley v. Baliles, 639 F. Supp. 680, 691 (E.D. Va. 1986); see also School Bd. of Richmond v. Baliles, 829 F.2d 1308, 1314 (4th Cir. 1987) (quoting same dicta). 
Contrary to the Bradley court's interpretation, the Swann Court was not referring to effects caused by unlawful school segregation but rather to harms inflicted by other kinds of discrimination, whether governmental or private:

The elimination of racial discrimination in public schools is a large task and one that should not be retarded by efforts to achieve broader purposes lying beyond the jurisdiction of school authorities. One vehicle can carry only a limited amount of baggage. It would not serve the important objective of Brown I to seek to use school desegregation cases for purposes beyond their scope, although desegregation of schools ultimately will have impact on other forms of discrimination. ${ }^{01}$

The Fourth Circuit affirmed the lower court's misuse of Swann, stating that although a state-mandated dual school system admittedly inflicts poverty on the students who receive an inferior education, a "school desegregation plan cannot remedy these general societal ills, even when they indirectly affect current students. ... Educational deficiencies that result from problems such as poverty are best remedied by programs directed toward eliminating poverty, not by indirect solutions through school programs."

The Fourth Gircuit's conclusion does not withstand close analysis. First, the issue is not one of remedying "general societal ills" or "educational deficiencies that result from problems such as poverty" but those deficits which have been caused by segregation-linked poverty. ${ }^{93}$ Second,

91. Swann v. Charlotte-Mecklenburg Bd. of Educ., 401 U.S. 1, 22-23 (1971) (emphasis added).

The Bradley court opined that educational relief for students attending RPS would necessitate state provision of direct compensation to individuals whose low income could be attributed to the prior segregation. However, the Supreme Court long ago precluded such a remedy by opting for equitable relief as the remedy for school segregation, rather than punitive or compensatory damages. See Brown II, 349 U.S. 294 (1955). For a discussion of the considerations which probably affected the Court's choice, see Shane, supra note 72 , at 1044-47.

The Eleventh Amendment also bars damage awards against states; indeed, Milliken II itself clearly distinguishes the provision of compensatory education from mere damage awards, finding the former permissible because it involves prospective injunctive relief. See Milliken $I I, 433$ U.S. at 289-90 \& n.21. This is not to suggest that any type of injunctive remedy would permissibly fall within the scope of Milliken II. For example, a post-graduation job training program for the victims of segregation arguably would be beyond the scope of relief because it would involve the creation and administration of new programs in areas of expertise beyond the knowledge and capability of school authorities. Where the sole remedy is educational remediation for children within the school system, the only practical burden is cost. However, as the district court in Jenkins made clear, "a consideration of [the] practicalities does not mean that the vindication of constitutional rights can be denied on 'any theory that it is less expensive to deny them than afford them." "639 F. Supp. 19, 23 (W.D. Mo. 1985) (quoting Watson v. Memphis, 373 U.S. 526, 537 (1963)), affd, 807 F.2d 657 (8th Cir. 1986), cert. denied, 108 S. Ct. 70 (1987).

92. School Bd. of Richmond v. Baliles, 829 F.2d 1308, 1314 (4th Cir. 1987).

93. For an important refutation of the approach to discrimination which the Bradley court and the Fourth Circuit assumed in this case, see B. Bittker, The Gase for Black Reparations 27 (1973): "Should no wrongs be corrected unless all can be? . . . [W] constantly compare competing demands for the redress of injustice, knowing full well that the pit is bottomless, especialy since the amelioration of one ill can cause a previously tolerable condition to seem degrading by comparison." However, Bittker's inquiry, like this Note, "presupposes a society that is prepared to respond to the 
it is not the role of the federal courts to relinquish a constitutional violator's duty to eliminate the effects of its own unconstitutional behavior by passing the buck to other governmental programs or actors lying beyond the jurisdiction of the courts. ${ }^{94}$ Third, even if we focus on "best" remedies, programs aimed at eliminating poverty are not the "best" remedy for educational deficiencies existing in current school-age children. Indeed, it is difficult to imagine a more suitable, let alone a more direct, solution for remedying the educational problems of students currently enrolled in a school system than providing compensatory education programs.

In sum, contrary to the recent Bradley and Fourth Circuit opinions, neither Milliken II nor the Supreme Court's general principles for limiting the exercise of equitable discretion in school desegregation cases preclude courts from ordering educational relief to remedy individualized harms that can be linked through socioeconomic injury to prior segregation. Legal recognition of these effects affirms equitable principles and is firmly within the discretion of federal courts: the established role of local school authorities can be "maintained inviolate"; the remedy is "indeed remedial"; and the order neither "punish[es] anyone," nor does it "impair or jeopardize [an] educational system."'9s

\section{Unitary Status and Compensatory Education Relief}

Federal circuit courts and legal commentators have largely ignored or minimized Milliken II in their attempt to set forth instructions for the identification of unitary school systems ${ }^{96}$ As a result, school desegregation

most meritorious of these claims, rather than dismissing all of them as man's ineluctable fate." See id.

94. See Jenkins v. Missouri, 593 F. Supp. 1485, 1505 (1984) ("[When] defendants have failed to comply with their constitutional obligations, this Court not only has the power but the duty to enter a decree which will correct the continuing effects of past discrimination as well as bar discrimination against blacks in the future.") (quoting Louisiana v. United States, 380 U.S. 145, 154 (1965)), affd, 807 F.2d 657 (8th Cir. 1986), cert. denied, 108 S. Ct. 70 (1987); see also Green v. County School Bd., 391 U.S. 430,438 n.4 (1968).

95. See Milliken II, 433 U.S. at 288; see also supra note 24.

96. See, e.g., United States v. Overton, 834 F.2d 1171, 1176 (5th Cir. 1987) (citing pre-Milliken II case, Pasadena v. Spangler, 427 U.S. 424, 436-37 (1976)) ("having once implemented a racially neutral attendance pattern in order to remedy the perceived constitutional violations on the part of the defendants, the District Court has fully performed its function of providing the appropriate remedy for previous racially discriminatory attendance patterns"); School Bd. of Richmond v. Baliles, 829 F.2d 1308, 1312 (4th Cir. 1987) (court does "not reject the possibility that in some circumstances it might be appropriate to use factors other than the kind described in Green"); United States v. Lawrence County School Dist., 799 F.2d 1031, 1034 (5th Cir. 1986) (unitary school district is one "in which schools are not identifiable by race and students and faculty are assigned in a manner that eliminates the vestiges of past segregation"); Riddick v. School Bd., 784 F.2d 521, 533 (4th Cir.) (unitary status achieved upon finding of integration in Green factors: faculty, staff, transportation practices, extracurricular activities, facilities and pupil assignment), cert. denied, $107 \mathrm{~S}$. Ct. 420 (1986); Terez, Protecting the Remedy of Unitary Schools, 37 CaSe W. Res. L. Rev. 41, 60 (1986) (proposing standard for unitariness that looks only at Green factors); Note, supra note 47, at 662 (citing Green, Swann, Alexander, and Keyes as precedent relevant to unitariness issue, ignoring Milliken II). But see Note, Unitary School Systems and Underlying Vestiges of State-Imposed Segregation, 87 Colum. L. REv. 794, 801-02 (1987) (recognizing need to eliminate effects of segregation on student achievement and educational programs, although minimizing effort required to eliminate sys- 
decrees may be wrongly terminated, without adequate attention to the unique systemic harms infecting a school system or the individualized harms borne by its pupils. Premature declarations of unitary status deny victims of segregation their right to full remediation of the violation and all of its effects.

Although the legal significance of a finding of unitary status has not been fully elaborated by the Supreme Court, the Court's limited discussion of the issue in Swann v. Charlotte-Mecklenburg Board of Education $^{97}$ indicates that judicial oversight of a violator school district will cease upon a declaration that a unitary school system has been achieved. ${ }^{98}$ A finding of unitary status would thus terminate outstanding desegregation decrees ${ }^{9 \theta}$ and eliminate the presumption that discriminatory effects are caused by the school district's purposeful action. ${ }^{100}$ Thereafter, plaintiffs would have to prove intentional segregation if they sought any change in school district practices. ${ }^{101}$ In effect, a declaration of unitariness would eliminate the legal relevance of the original constitutional violation.

Although the Supreme Court's desegregation jurisprudence has not provided guidelines for determining when unitary status itself has been achieved, ${ }^{102}$ it does provide some clues for the way in which lower federal

temic harms).

97. 402 U.S. 1 (1971).

98.

At some point, these school authorities and others like them should have achieved full compliance with this Court's decision in Brown I. The systems would then be 'unitary' .... This does not mean that federal courts are without power to deal with future problems; but in the absence of a showing that either the school authorities or some other agency of the State has deliberately attempted to fix or alter demographic patterns to affect the racial composition of the schools, further intervention by a district court should not be necessary. 402 U.S. at 31-32.

99. See Overton, 834 F.2d at 1175 (attaining unitary status means end of judicial superintendence); Morgan v. Nucci, 831 F.2d 313, 318 (1st Cir. 1987) ("one thing certain about unitariness is its consequences: the mandatory devolution of power to local authorities"); Riddick, 784 F.2d at 535 ("[O]nce the goal of a unitary school system is achieved, the district court's role ends."); Note, supra note 96, at 795. But see Dowell v. Board of Educ., 795 F.2d 1516, 1520 (10th Cir. 1986) (finding of unitariness does not divest a court of its jurisdiction without specific dissolution of ongoing desegregation decree), cert. denied, 107 S. Ct. 420 (1986); Terez, supra note 96, at 60-65 (inherent in finding of unitariness should be injunction requiring permanent maintenance of unitary school system).

100. See supra note 47.

101. See Overton, 834 F.2d at 1175 (end of judicial superintendence means more than absence of injunction and pending suit; school district must be released from burden of proving its decisions are free of segregative purpose); Riddick, 784 F.2d at 538 ("burden of proving discriminatory intent attaches to a plaintiff once a de jure segregated school system has been found to be unitary"). But see Note, supra note 47, at 669 (1987) (even after finding of unitary status defendants retain burden of proving that reestablishment of dual school system is not intentional after showing by plaintiffs of substantial resegregation); Morgan, 831 F.2d at $326 \mathrm{n} .19$ (citing Note, supra note 47, recognizing a "possibility" that some burden might fall on defendants even after finding of unitariness).

102. The Supreme Court has held that once a plaintiff has proved the existence of unlawful segregation, a school system is under a continuing duty to take whatever steps are necessary to completely eliminate racial discrimination and its effects. See Dayton II, 443 U.S. 526, 538 (1979); Columbus Bd. of Educ. v. Penick, 443 U.S. 449, 458-59 (1979); Swann v. Charlotte-Mecklenburg Board of Educ., 402 U.S. 1, 15 (1971).

Prior to a finding of unitary status, the school board shoulders the burden of proving that its actions or inaction have not perpetuated the effects of the illegal dual system. See Dayton II at 537-38; 
courts should proceed when considering unitary status. For example, the Court in Milliken II eschewed a formulaic response to desegregation, recognizing the uniqueness of each constitutional violation. ${ }^{103}$ Thus, rather than looking to an external definition of unitariness, ${ }^{104}$ a district court considering conferring unitary status on a violator school district should instead determine whether the particular effects in the case before it have been eliminated.

Some circuit courts now struggling to identify unitary school systems ${ }^{105}$ appear to have forgotten the Supreme Court's admonition to defer to particularized fact-finding and remediation. Instead, they have transformed certain systemic factors-faculty, staff, transportation, extracurricular activities, and facilities-that the Supreme Court pointed to in Green v. County School Board as indicative of racial identifiability, into predetermined criteria for assessing progress toward unitary status. ${ }^{106}$

The circuit courts' misplaced reliance on Green overlooks the preceden-

Vaughns v. Board of Educ. of Prince George's County, 758 F.2d 983, 991 (4th Cir. 1985). A school board's progress toward achieving unitary status is measured not by its good intentions but by its effectiveness. See Davis v. Board of School Comm'rs, 402 U.S. 33, 37 (1971) ("The measure of any desegregation plan is its effectiveness."); Dayton II, 443 U.S. at 538; Green, 391 U.S. at 439 ("IW]hatever plan is adopted will require evaluation in practice, and the court should retain jurisdiction until it is clear that state-imposed segregation has been completely removed."). But see Morgan v. Nucci, 831 F.2d 313, 321 (1st Cir. 1987) (whether school defendants have demonstrated good faith in desegregation effort and operation of schools is factor to be considered in determining unitary status); United States v. Overton, 834 F.2d 1171, 1173 (5th Cir. 1987) (desegregation case settled by consent decree calling for court to retain jurisdiction for only three years, after which Austin Independent School district would be declared unitary, and case dismissed absent objection).

103. The Court has traditionally left it to the lower federal courts to give content to general principles in light of local realities:

This Court has from the beginning looked to the District Courts in desegregation cases, familiar as they are with the local situations coming before them, to appraise the efforts of local school authorities to carry out their constitutionally required duties. 'Because of their proximity to local conditions .... the [federal district] courts which originally heard these cases can best perform this judicial appraisal.'

Milliken II, 433 U.S. at 287 n.18 (quoting Brown II, 349 U.S. 294, 299 (1955)).

104. For an attempt to provide courts with such a definition, see Terez, supra note 96, at 60: 'Unitariness,' as a remedy to racially segregated public schools, entails the unavoidably difficult transition from racially identifiable schools to fully integrated schools where no distinctions are made on the basis of race in such key areas as faculty, staff, transportation, extracurricular activities, facilities, and student bodies. Furthermore, 'unitariness' calls for the elimination of all vestiges of racial discrimination in public schools and the maintenance of public schools which cannot be identified on the basis of race in any of the key areas.

105. Although the Supreme Court has always spoken in terms of the achievement of a unitary school system, one circuit court has concluded that unitary status may be conferred in an incremental fashion. See Morgan, 831 F.2d at 318-19 (wrongly citing Pasadena v. Spangler, 427 U.S. 424, 436-37 (1976), for proposition that a district court may confer unitary status on pupil assignments even if other facets of the school system retain discriminatory vestiges).

106. See supra note 96 (discussing United States v. Overton, 834 F.2d 1171, 1176 (5th Cir. 1987); School Bd. of Richmond v. Baliles, 829 F.2d 1308, 1312 (4th Cir. 1987); United States v. Lawrence County School Dist., 799 F.2d 1031, 1034 (5th Cir. 1986); Riddick v. School Bd., 784 F.2d 521, 533 (4th Cir. 1986), cert. denied, 107 S. Ct. 420 (1986)). But see Green, 391 U.S. at 439: The obligation of the district courts, as it always has been, is to assess the effectiveness of a proposed plan in achieving desegregation. There is no universal answer to complex problems of desegregation: there is obviously no one plan that will do the job in every case. The matter must be assessed in light of the circumstances present and the options available in each instance. 
tial significance of subsequent Supreme Court case law, which has expanded judicial recognition of the remediable effects of segregation. As noted above, the Supreme Court has discussed at length the effect that unlawful school construction and closing policies can have on residential segregation, and declared that such an effect must be considered in assessing the effectiveness of a pupil assignment remedy ${ }^{107}$ And in Milliken II, the Court not only extended its conception of the systemic vestiges that may require elimination before unitary status can be achieved beyond that it had articulated in Green, but recognized that the individualized effects of unlawful segregation may also need remediation. ${ }^{108}$ Thus, before moving to terminate an outstanding school desegregation decree, a federal court must ensure that the particular effects in the case at hand, whether racially-skewed assignment policies, segregated housing patterns, or low achievement scores, have been eliminated.

\section{Gonclusion}

Ten years ago, Milliken II created an opportunity for the complete elimination of unlawful segregation and its continuing effects. Many lower federal courts have seized upon its broadly stated corrective principles to provide extensive compensatory education relief. Although the Supreme Court recognized that the harms of segregation affect both individuals and the educational system, some recent decisions have minimized or failed to apply this holding. The Fourth Circuit's recent move to limit the cognizable effects of compensatory education remedies undermines the Supreme Court's school desegregation jurisprudence and should be rejected by other circuits. Finally, the emerging case law in the area of termination of school desegregation remedies must recognize that remedying unlawful segregation and its effects may require educational compensation for its victims.

107. See supra notes 36-39 and accompanying text; see also Note, supra note 96, at 802 ("A busing plan is not so much intended to eliminate underlying residential segregation . . . as it is to counteract the resulting segregation in neighborhood schools. The consequence of this distinction is that successful implementation of a desegregation plan does not permanently eradicate underlying vestiges, they remain lurking beneath the plan.").

The importance of eliminating residential segregation caused by intentional school segregation has become apparent in three recent cases in which a finding of unitariness was followed by a return to neighborhood school assignment plans that resulted in a substantial increase in the number of allblack schools within the district. See, e.g, United States v. Overton, 834 F.2d 1171, 1174 (5th Cir. 1987); Riddick v. School Bd., 784 F.2d 521, 536 (4th Cir. 1986), cert. denied 107 S. Ct. 420 (1986); Dowell v. Board of Educ., 795 F.2d 1516, 1518 (10th Cir. 1986), cert, denied, 107 S. Ct. 420 (1986); Note, supra note 96, at 809.

108. See supra Section I. 